\title{
CHALLENGES IN DEVELOPMENT OF SMART CITIES IN WESTERN BALKANS
}

\author{
Vladimir Tomašević ${ }^{1}$ \\ Luka Latinović ${ }^{2}$
}

DOI: https://doi.org/10.31410/LIMEN.2020.323

\begin{abstract}
Western Balkans have several definitions depending on the lens through which this concept is observed. The definitions can be economic, political or economic. The analysis is further complicated by the partial presence of the European Union, various economic treaties and unresolved conflicts as well as the fact that the largest urban populations are scattered without definitive trends. Cities continue to attract new arrivals as a result of the direct centralization tendencies throughout the region and result in an unsustainable growth of cities that in turn result in economic and social complications. This article uses a matrix classification model to classify the existing literature on cities in Western Balkans, identify specific conditions for particular groups and proposes different approaches for groups of cities in order to maximise the effects of smart cities projects so that doubling and significant overlapping in financing are avoided.
\end{abstract}

Keywords: Western Balkans, Smart cities, Challenges, Urban development, Infrastructure.

\section{INTRODUCTION}

$\mathrm{T}$

The Balkan Peninsula, geographically speaking, is region of Southeast Europe bounded by the Adriatic Sea to the west, the Mediterranean Sea (including the Ionian and Aegean seas) Marmara Sea to the south, Black Sea to the east, and rivers Sava, Kupa, and Danube to the north (Jelavich, 1999). This is the only parameter with which all nations that are in this region agree. In fact, there is no wide consensus on what the nations are ${ }^{3}$ Geographically speaking, Western Balkans are comprised of the following countries: Slovenia, parts of Croatia, Bosnia and Herzegovina, parts of Serbia, Montenegro, North Macedonia, and Albania (De Agostini, 2004). Politically, Slovenia and Croatia are traditionally exempt from this categorization as they are members of the European Union (De Munter, 2020). Therefore, it can be concluded from the aforementioned that a model for defining "Western Balkans" is needed before further studies can be conducted.

Cities as a social phenomenon are another dimension to this research. Given that it is estimated that over $72 \%$ of European inhabitants live in urban areas, several studies have been conducted in order to classify them, and traditionally, the focus has been on large metropolitan areas (Taylor, 2003). However, Giffinger et al. (2007) correctly identify that there is "a deficit in literature ... by exploring medium-sized cities and their perspectives for development" (p.3), and thus have provided a model for evaluating generic European cities, particularly as their research focuses on cities with 100,000-500,000 inhabitants which constitute approximately

Faculty of Engineering Management, Belgrade, Bulevar vojvode Mišića 43, Belgrade, Serbia Faculty of Engineering Management, Belgrade, Bulevar vojvode Mišića 43, Belgrade, Serbia Kosovo is an integral part of Serbia and its designation is without prejudice to positions on status, and in line with UNSCR 1244 and the ICJ Opinion on the Kosovo Declaration of Independence. 
$44 \%$ of the urban population in Europe (Nordregio et al., 2004). Aditionally, Lopez \& Oliviera (2017) prove that "beyond doubt that small and medium sized cities do not lag behind the large ones when it comes to "smart cities" and that they have huge potential to make their mark in this concept" (p. 624). Therefore, it can be concluded from the aforementioned that a specific model for defining and assessing cities in the "Western Balkans" is needed before further studies can be conducted.

\section{DEFINING THE WESTERN BALKANS}

In order to achieve a certain regional identity and cooperation, it is important to understand common features and challenges that each country has to overcome. Achieving consensus on these common factors is one of the conditions to pave the way for overcoming common obstacles. The Balkans geographically include a large number of countries (bordering Italy in the West, Ukraine in the Northeast and Turkey in the Southeast) involved in numerous historical and political processes in the region. The Balkans have a very turbulent history associated with wars and ethnic conflicts. In the historical literature, one can find the Balkans described even as a "European part of Turkey". Delevic (2007) argues that "This has inhibited a sense of belonging to a particular regional community, and hence also the development of any regional strategy" (p. 11). A great number of dividing lines, spheres of interest and integration projects make it difficult to talk about clear boundaries in the same categories like, for example, in South America. Geographically, the Western Balkans are comprised of the following countries: parts of Serbia, parts of Slovenia, parts of Croatia, Bosnia and Herzegovina, Montenegro, North Macedonia, and Albania (De Agostini, 2004). Such provisional notion as 'Western' is not uncommon in literature. To more accurately determine the set of countries and common factors in question, researchers often add additional notations. Therefore, in modern literature, determinants such as Southeast Europe, Western Balkans, Western Balkan Six are most often encountered. However, each of these notions, as Entina \& Pivovarenko (2020) argue, "include different sets countries depending on the political contextualisation”. Kolstø (2016) noted that the term 'Balkans' was reinserted into the official political lexicon of Europe from the late 1990s onwards, however with the aforementioned specifier 'Western'. As he argued "'The Western Balkans' became the correct designation in the EU for non-members located in the south eastern part of Europe. At that time the word 'Balkan' was used increasingly less for countries in the southern, eastern and northern parts of the peninsula: they had become EU members" (Kolstø, 2016). Bulgaria and Romania became EU members in 2007. Among the other post-communist European states, Croatia, as 'late transitionist', was also able to successfully follow this path and became a member in 2013 . This observation by Kolst $\varnothing$ can be reflected in research by Croatian authors. An example would be research by Devetak (2019) who used the term Western Balkans to denominate the geopolitical area that includes the former republics of Yugoslavia (Bosnia and Hercegovina, North Macedonia, Montenegro, Serbia and Albania). Furthermore, Devetak (2019) argues that the Western Balkans corresponds to "neither to geographic nor geopolitical realities" and that "it was "invented" by the EU in order to divide Bulgaria and Romania that were supposed to become the EU members from other Balkan countries".

Similarly, on a question of whether the Western Balkans can be classified as a separate region, theorists from the Copenhagen School, Barry Buzan and Ole Waever, in 2003 also gave a negative answer. They stated that "Due to the asymmetry of power between the actors in and around the Balkans, it is in the hands of the external powers to 'force' the Balkans into the European complex" (p. 377). They argued that there were no strong regional or global powers here, which would be the key political and security "stakeholder". However, although Slovenia 
e.g., joined the EU in 2004 and only partially belongs to the Balkans, geographically both Slovenia and Croatia still belong to the Western Balkans and share similar challenges with neighbouring countries. Furthermore, if things are viewed through this perspective, of the common challenges that these countries need to overcome in order to prosper economically in these economically volatile times, it could be argued that there are more than enough elements going in favour of cooperation voluntarily. If the Western Balkans were seen as an emerging region in transition, then it is obvious that the economic development is underway and, in such an environment, cooperation should be seen as an obvious choice, rather than the last option imposed externally by geopolitics. In addition, the Regional Cooperation of the Western Balkans is one of the cornerstones of the European Union's policy of conditionality towards this part of Europe. This means that regional cooperation is the conditio sine qua non for the accession of countries to the EU. Having that in mind, the paper by Beširević \& Cujzek (2013) defines the Western Balkans as a region that includes the countries of the Stabilization and Association Process, which are Albania, Bosnia and Herzegovina, Montenegro, Croatia, Kosovo under UN Declaration 1244, Macedonia and Serbia. Although different countries, as shown, try to tailor the region to suit their own political agendas, for the purpose of this paper the Western Balkans will be regarded as the region comprised of all countries of the former Socialist Federal Republic of Yugoslavia with the addition of Albania. This includes Serbia, Slovenia, Croatia, Bosnia and Herzegovina, North Macedonia and Albania.

\section{DEFINING THE SMART CITY CONCEPT}

Abandonment of rural areas in favour of cities has led to the unprecedented challenges of urban sustainability (Han et al., 2017). Information and communication technologies (ICT) have already emerged as pivotal tools in coping with these challenges. These three major trends: urbanisation, sustainability and ICT are constituents of a long-term vision called 'Smart City'. Although there is no generally accepted definition, the concept of a smart city could be described as a comprehensive and long-term approach towards sustainable urban living, while respecting the environment. It is a paradigm related to cities that develop cyber-infrastructure ("smart grids", ICT, intelligent transport systems, etc.) with the aim to foster sustainable economic growth and better quality of life (Bibri \& Krogstie, 2019); reduce generated pollution; improve natural resources and waste management (Bueno-Delgado, 2019), while preserving competitiveness in an increasingly globalised environment (Miłaszewicz, 2014). The importance of this concept is also reflected in regional and urban development policy of the European Union, where the "greener" technology is recognized as an advantage in reducing greenhouse gas emissions and promoting the city's collective intelligence and innovation. However, due to different economic and geographical characteristics, each urban environment has different resources and specific local problems. Therefore, the methods for the development and implementation of the smart city concept also differ. Mattoni et al. (2015) believe that the Vienna Polytechnic University and the University of Ljubljana developed a definition of Smart City that seems to have led to the first change of perspective and introduced a new paradigm of urban living. Six "axes" were introduced, along which the "level of smartness" of seventy Central European cities could have been evaluated, not only in terms of ICT implementation but also in terms of mobility, environmental quality, social life, governance, economy and in general, the quality of life. Different cities have developed different methods, strategies, models and frameworks for their implementation of this concept. It is foremost necessary to understand which determinants make the main bottlenecks in existing urban practices. As Bibri \& Krogstie (2019) explain, "this involves identifying the stumbling blocks on the way and the key stakeholders that should be involved to drive change, as well as developing and assessing the policy pathway in terms of planning practices and 
development strategies necessary to achieve the future outcome". Additionally, it should be noted that despite the common belief, "smart" does not necessarily mean or include "ICT".

\section{FRAMEWORK FOR SMART CITIES CLASSIFICATION}

In order to provide a theoretical contribution to the intercity and regional cooperation and "know-how" dissemination between Western Balkans' cities, this paper classifies them based on their common sustainability challenges. There are also several sustainability problems common for all Western Balkans' countries and cities such as population aging and decline (Eurostat, 2021), increased social cohesion problems, political instability and economic recession. Cities were classified into four major groups: capitals, ports, coastal cities and, former communist industrial centres. It should be noted that Table 1 does not include all, but the most representative cities, regarding the common challenges and that the former communist industry centres also include all Capitals.

Table 1. Matrix of Western Balkan cities based on common attributes and challenges in smart city transition

\begin{tabular}{|c|c|c|}
\hline & Cities & Common challenges \\
\hline Capitals & $\begin{array}{l}\text { Belgrade (RS) } \\
\text { Zagreb (CRO) } \\
\text { Ljubljana (SLO) } \\
\text { Sarajevo (BiH) } \\
\text { Podgorica (MN) } \\
\text { Skopje (MK) } \\
\text { Tirana (AL) }\end{array}$ & $\begin{array}{l}\text { Excessive immigration leading to the undirected } \\
\text { expansion beyond long-term city plans. The pace } \\
\text { of urbanisation with traffic congestion and } \\
\text { pollution leads to deteriorating quality of life. } \\
\text { Frequent intertwining of city and state interests } \\
\text { and jurisdictions leading to inefficient investing in } \\
\text { projects needed by these cities. }\end{array}$ \\
\hline Ports & $\begin{array}{l}\text { Novi Sad (RS) } \\
\text { Koper (SLO) } \\
\text { Split, Rijeka (CRO) } \\
\text { Bijela, Tivat, } \\
\text { Kotor (MN) } \\
\text { Durres (AL) }\end{array}$ & $\begin{array}{l}\text { Port management needs to introduce } \\
\text { environmental and social objectives. Intertwining } \\
\text { of terminals and railway, road and ship traffic. } \\
\text { Emphasis on logistics and traffic organisation in } \\
\text { already congested areas. }\end{array}$ \\
\hline $\begin{array}{c}\text { Coastal } \\
\text { cities }\end{array}$ & $\begin{array}{l}\text { Koper (SLO) } \\
\text { Rijeka, Pula, Split, } \\
\text { Dubrovnik (CRO) } \\
\text { Herceg Novi, Kotor, } \\
\text { Tivat (MN) } \\
\text { Durres (AL) }\end{array}$ & $\begin{array}{l}\text { Sustainability of coastal cities highly threatened by } \\
\text { the climate crisis and mass tourism. Cruise tourism } \\
\text { creates large influx of tourists in a short time } \\
\text { creating significant logistical problems. Water } \\
\text { consumption and waste management issues. } \\
\text { Excessive dependence on tourism, which proved } \\
\text { to be serious disadvantage during the COVID19 } \\
\text { pandemic. }\end{array}$ \\
\hline $\begin{array}{c}\text { Former } \\
\text { communist } \\
\text { industrial } \\
\text { centres }\end{array}$ & $\begin{array}{l}\text { Valjevo, Smederevo, } \\
\text { Cacak, Kragujevac, } \\
\text { Krusevac (RS) } \\
\text { Velenje, Maribor } \\
\text { (SLO) Buje, Karlovac, } \\
\text { Bjelovar, (CRO) } \\
\text { Banja Luka, Mostar, } \\
\text { Bihac, Tuzla (BiH) } \\
\text { Cetinje, Niksic (MN) }\end{array}$ & $\begin{array}{l}\text { Former communist industry went through a mass } \\
\text { privatisation. New companies are not interested in } \\
\text { investing in infrastructure and regarding cities as a } \\
\text { one-time resource to extract money while creating } \\
\text { an ecological Ponzi scheme. The major challenge } \\
\text { is to force companies to invest in long-term } \\
\text { infrastructure projects that go in line with the smart } \\
\text { city concept. }\end{array}$ \\
\hline
\end{tabular}




\section{CONCLUSION}

The outcome of urbanisation can be perceived positively, with urban areas being considered as the backbone of the Western Balkans economy and development, boosting creativity and innovation. However, it can be perceived negatively, with overcrowded and congested living and traffic areas, excessive use of resources, irrational consumption patterns, overproduction of waste, air pollution, unemployment, poverty, rural decay, migration, etc.

\section{REFERENCES}

Beširević, N., \& Cujzek, I. (2013). Regionalna politika Europske unije prema Zapadnom Balkanu - dosezi i ograničenja. Politicka Misao: Croatian Political Science Review, 50(1), 155-179.

Bibri, S. E., \& Krogstie, J. (2019). Generating a vision for smart sustainable cities of the future: a scholarly backcasting approach. European Journal of Futures Research, 7(1), N.PAG. https://doi.org/10.1186/s40309-019-0157-0

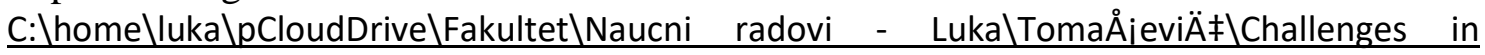
Develpoment of Smart Cities in Western Balkans2.docBueno-Delgado, M.-V., RomeroGázquez, J.-L., Jiménez, P., \& Pavón-Mariño, P. (2019). Optimal Path Planning for Selective Waste Collection in Smart Cities. Sensors, 19(9), 1973. https://doi.org/10.3390/s19091973

Buzan, B., \& Waever, O. (2013). Regions and powers: The structure of international security. In Regions and powers: The structure of international security (pp. 377-378). Cambridge: Cambridge University Press.

Delevic, M. (2007). Chaillot Paper n ${ }^{\mathrm{o}} 104$ - Regional cooperation in the Western Balkans. Paris: Institute for Security Studies.

Devetak, S. (2019). Reconciliation - a Prerequisite for the Integration of Western Balkans in the Eu Stream of Values. Balkan Social Science Review, 14, 179-201.

Entina, E., \& Pivovarenko, A. (2020). Russia's Foreign Policy Evolution in the New Balkan Landscape. Politička Misao, 56(3-4), 179-199. doi:10.20901/pm.56.3-4.08

Eurostat. (2021). Selection of figures on the Western Balkans. Available at: https://ec.europa.eu/eurostat/news/themes-in-the-spotlight/western-balkans-2019 Accessed: 2/27/2021.

Han, J., Meng, X., Zhou, X., Yi, B., Liu, M., \& Xiang, W.-N. (2017). A long-term analysis of urbanization process, landscape change, and carbon sources and sinks: A case study in China's Yangtze River Delta region. Journal of Cleaner Production, 141, 1040-1050. https://doi.org/10.1016/j.jclepro.2016.09.177

Kolstø, P. (2016). 'Western Balkans' as the New Balkans: Regional Names as Tools for Stigmatisation and Exclusion. Europe-Asia Studies, 68(7), 1245-1263. https://doi.org/10.1080/09668136.2016.1219979

Mattoni, B., Gugliermetti, F., \& Bisegna, F. (2015). A multilevel method to assess and design the renovation and integration of Smart Cities. Sustainable Cities and Society, 15, 105119. doi:10.1016/j.scs.2014.12.002

Miłaszewicz, D. (2014). Sustainable Competitiveness - Analisis Of Economies At Various Levels Of Development. Ekonomia I Prawo, 13(4), 511. doi:10.12775/eip.2014.036

\section{ADDITIONAL READING}

De Munter, A. (2020). Fact Sheets on the European Union (11). European Parliament. https://www.europarl.europa.eu/ftu/pdf/en/FTU_5.5.2.pdf 
Giffinger, R., Fertner, C., Kramar, H., Kalasek, R., Milanović, N. \& Meijers, E. (2007) Smart cities - Ranking of European medium-sized cities. Vienna, Austria: Technical University Vienna

Istituto Geografico De Agostini (Ed.) (2004), L'Enciclopedia Geografica - Vol. I, Italia: De Agostini

Jelavich, B. (1999). History of the Balkans: Eighteenth and Nineteenth Centuries. Cambridge: Cambridge University Press.

Nordregio et al. (2004). ESPON 1.1.1: Potentials for polycentric development in Europe, Project report, Stockholm/Luxembourg: Nordregio/ESPON Monitoring Committee

Taylor, P.J. (2003) World City Network: a Global Urban Analysis. London: Routledge. 